\title{
ANALISA POTENSI GAS RUMAH KACA HASIL DARI LIMBAH INDUSTRI MANUFAKTUR DI JAWA TIMUR
}

Oleh :

WENDY TRIADJI NUGROHO *)

\begin{abstract}
ABSTRAK
Gas-gas rumah kaca (GRK) merupakan gas-gas di atmosfer yang memiliki efek penyelimutan karena gas-gas tersebut menyerap panas yang dilepaskan oleh permukaan bumi. GRK yang dipengaruhi langsung oleh kegiatan manusia adalah karbon dioksida $\left(\mathrm{CO}_{2}\right)$, metan $\left(\mathrm{CH}_{4}\right)$, nitrous oksida $\left(\mathrm{N}_{2} \mathrm{O}\right)$, klorofluorokarbon (CFC) dan ozon.

Metode yang diterapkan dalam penelitian ini adalah survei lapang untuk mengumpulkan informasi mengenai limbah industri manufaktur di wilayah Jawa Timur, selanjutnya dihitung emisi GRK nya dan dibandingkan dengan Baku Mutu Emisi untuk menentukan apakah emisi yang dihasilkan oleh industri manufaktur itu masih di bawah ambang ataukah sudah melampau ambang batas.

Dari hasil perhitungan dan analisa dapat diketahui bahwa limbah yang dihasilkan oleh beberapa industri di Jawa Timur menyatakan bahwa emisi GRK industri tersebut berada di bawah ambang batas yang telah ditentukan.
\end{abstract}

Kata Kunci : Gas Rumah Kaca, Industri Manufaktur, Emisi, Baku Mutu Emisi 


\section{PENDAHULUAN}

\section{Latar Belakang}

Peningkatan konsentrasi Gas Rumah Kaca (GRK) yang meliputi $\mathrm{CO}_{2}, \mathrm{CH}_{4}, \mathrm{~N}_{2} \mathrm{O}, \mathrm{SF}_{6}$, HFC dan PFC sebagai akibat aktivitas manusia telah menyebabkan meningkatnya radiasi sinar Ultra Violet yang terperangkap di atmosfer. Peningkatan radiasi ini memberikan kontribusi pada fenomena pemanasan global (global warming) yaitu meningkatnya suhu permukaan bumi. Global warming menyebabkan perubahan pada unsur-unsur iklim seperti halnya kenaikan temperatur permukaan bumi, bertambahnya jumlah penguapan di udara, berubahnya pola curah hujan dan tekanan udara. Itu semua pada akhirnya dapat mengubah pola iklim dunia.

Salah satu faktor penyebab meningkatnya GRK adalah limbah industri manufaktur. Dalam hal ini yang menjadi sumber data penelitian adalah limbah industri manufaktur di Provinsi Jawa Timur.

\section{Permasalahan}

Masalah yang ingin diteliti adalah berapakah jumlah emisi GRK yang diproduksi oleh beberapa industri manufaktur di Jawa Timur dan selanjutnya akan dibandingkan dengan Baku Mutu Emisi yang telah ditetapkan.

\section{Batasan Masalah}

Ruang lingkup penelitian adalah :

- waktu pengambilan data adalah antara bulan Januari-Desember 2012

- Jangkauan penelitian hanya mencakup Propinsi Jawa Timur

- Industri manufaktur diteliti adalah industri logam, semen, pulp dan kertas, pupuk, gula, serta Pembangkit Listrik Tenaga Gas berbahan bakar batu bara

\section{Tujuan Penelitian}

Tujuan yang ingin dicapai dalam penelitian ini adalah untuk mengetahui apakah emisi Gas Rumah Kaca yang dihasilkan beberapa industri manufaktur di Jawa Timur melampaui ambang batas ataukan tidak.

\section{METODOLOGI}

\section{Waktu dan Tempat Penelitian}

Penelitian dilaksanakan pada bulan Januari sampai dengan Desember 2012. Lokasi penelitian adalah di beberapa perusahaan manufaktur di Jawa Timur dan Laboratorium Teknik Energi Terbarukan- Politeknik Negeri Jember.

\section{Bahan dan Alat}

Bahan yang digunakan adalah emisi limbah industri manufaktur berupa gas-gas $\mathrm{CO}_{2}$, $\mathrm{CH}_{4}, \mathrm{~N}_{2} \mathrm{O}, \mathrm{SF}_{6}, \mathrm{HFC}$ dan PFC yang merupakan pemicu efek Gas Rumah Kaca. Sedangkan peralatan yang dipakai adalah Aeroqual AQM60 Ambient Air Monitoring, Real time data acquisition, PC software, Pole atau wall installation, kalibrasi Zero and Span, sensor kecepatan dan arah angin, serta sensor temperatur dan kelembaban.

\section{Metode Pelaksanaan \\ 3.1 Pengambilan data}

Data-data diperoleh dari pengukuran suhu dan kelembaban udara, pengukuran kecepatan dan arah angin, dan pengukuran partikel-partikel gas limbah industri.

Beberapa industri yang diambil data emisinya ditunjukkan oleh gambar 1, 2 dan 3 .

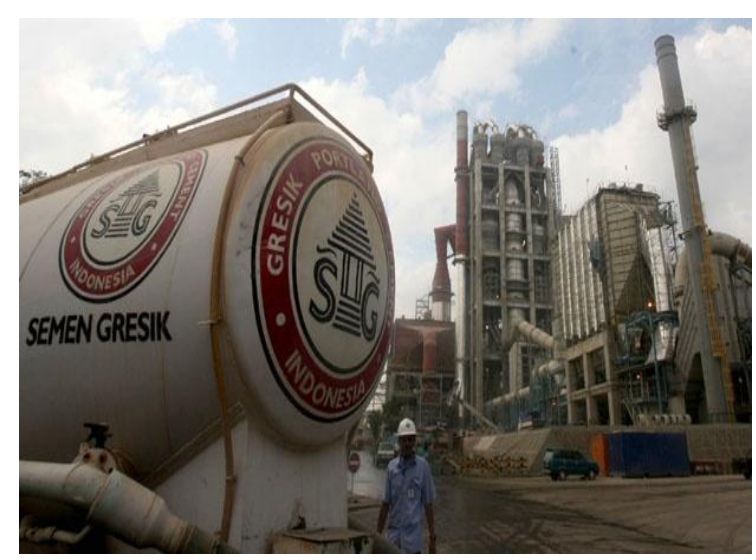

Gambar 1. PT. Semen Gresik 


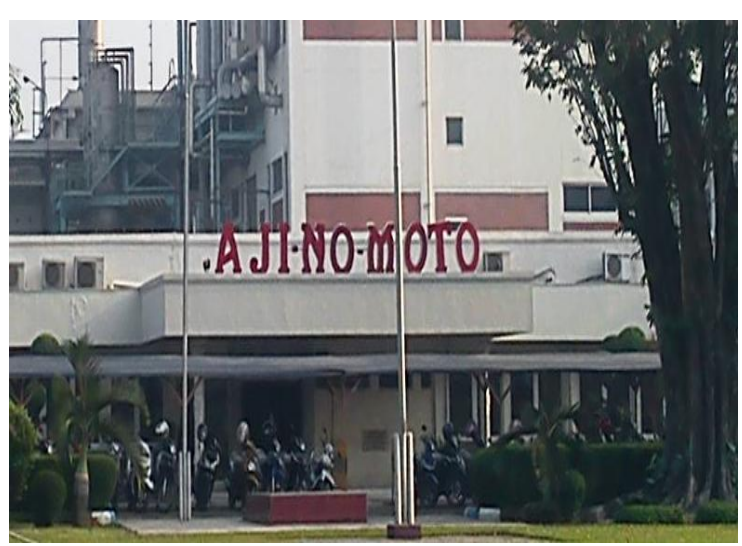

Gambar 2. PT. Ajinomoto

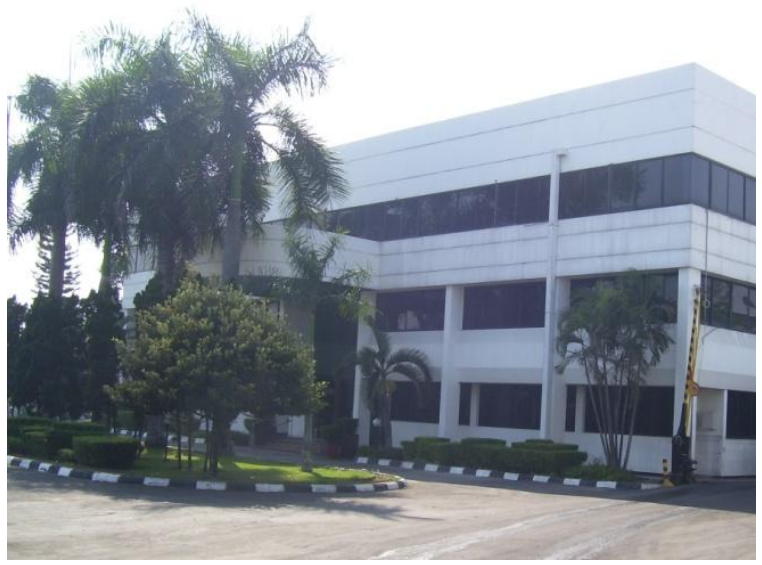

Gambar 3. PT. Pakerin

\subsection{Pengolahan data}

Data-data hasil pengukuran diolah dengan menggunakan software Aeroqual AQM60 Ambient Air Monitoring dan Microsoft Excell yang dibagi menjadi beberapa tahap yaitu :

- pengelompokan data yang berasal dari sistem data akuisisi (Real time data acquisition)

- mengolah data-data tersebut di software Microsoft Excell.

Adapun langkah-langkah untuk memperoleh nilai emisi GRK adalah sebagai berikut

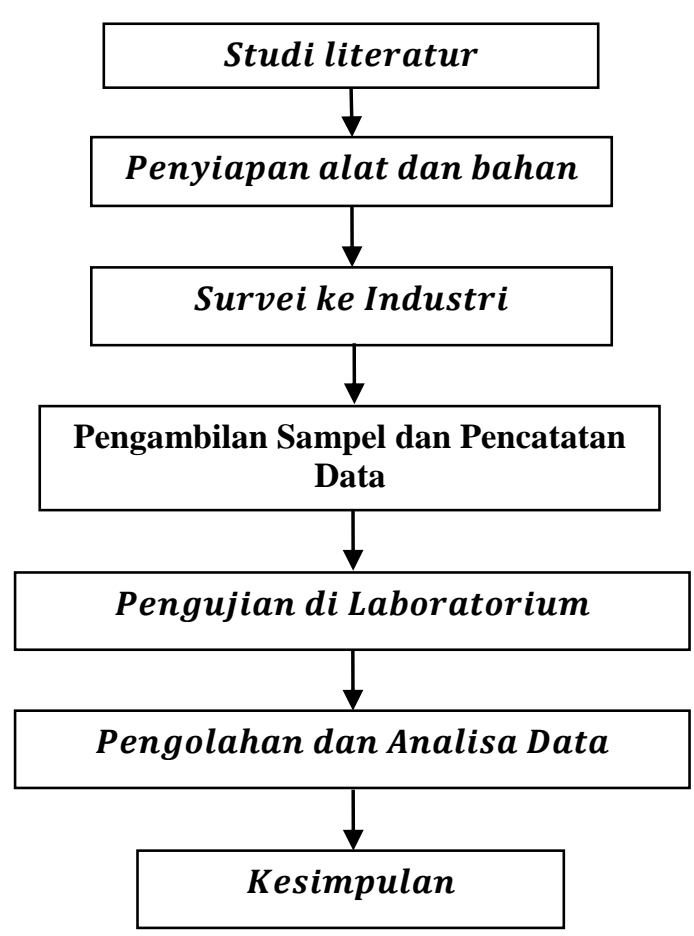

Gambar 4. Langkah-langkah penelitian

Berikut ini adalah formula untuk menghitung emisi Gas Rumah Kaca.

$$
\text { Emisi }_{\mathrm{GRK}}=\Sigma \mathrm{A}_{\mathrm{i}} \mathrm{x} \mathrm{EF}_{\mathrm{i}}
$$

Dimana :

Emisi GRK = Emisi suatu Gas Rumah Kaca (CO2, CH4, N2O)

$\mathrm{Ai} \quad=$ Data Aktivitas Industri manufaktur $\mathrm{i}$

$\mathrm{EFi}=$ Faktor Emisi dari Industri manufaktur i

Faktor emisi yang dipergunakan tergantung ketersediaan data dan informasi selama penelitian. Faktor emisi berdasarkan ketelitiannya secara berurutan adalah:

1) hasil pengukuran,

2) data faktror emisi lokal (Indonesia) dan

3) default dari IPCC (2006).

\section{DATA HASIL PENGUKURAN DAN PEMBAHASAN}

\section{Data Hasil Pengukuran}

Hasil perhitungan jumlah emisi GRK yang dihasilkan dari sektor industri ini di Jawa Timur yang berasal dari indurti semen, industri kapur, indusrti kimia, industri logam, dan 
Wendy Triadji N, Analisa Potensi Gas Rumah Kaca Hasil Dari Limbah Industri Manufaktur Di Jawa Timur

industri elektronik disajikan oleh Tabel 1 hingga Gambar 13 berikut ini.

Tabel 1. Hasil Perhitungan Emisi $\mathrm{CO}_{2}$ dari Industri Kapur

\begin{tabular}{|l|l|r|r|r|}
\hline \multicolumn{1}{|c|}{ Nama Perusahaan } & Produk & Produksi & $\begin{array}{c}\text { Satu } \\
\text { an }\end{array}$ & $\begin{array}{c}\text { Emisi } \\
\text { CO2 } \\
\text { (ton/ta } \\
\text { hun) }\end{array}$ \\
\hline $\begin{array}{l}\text { PT. SUMBER TAMAN } \\
\text { KERAMIK }\end{array}$ & $\begin{array}{l}\text { Kapur } \\
\text { Tulis }\end{array}$ & 378 & Ton & 0,08 \\
\hline $\begin{array}{l}\text { Camco Omya Indonesia } \\
\text { (Ind. Kalsium Karbonat) }\end{array}$ & $\begin{array}{l}\text { Kalsium } \\
\text { Karbonat }\end{array}$ & 240.000 & Ton & 48,00 \\
\hline $\begin{array}{l}\text { Camco Omya Indonesia } \\
\text { (Ind. Kalsium Karbonat) }\end{array}$ & $\begin{array}{l}\text { Kalsium } \\
\text { Karbonat }\end{array}$ & 240 & Ton & 0,05 \\
\hline $\begin{array}{l}\text { INDOBENT WIJAYA } \\
\text { MINERAL }\end{array}$ & $\begin{array}{l}\text { Tepung } \\
\text { Bentonite }\end{array}$ & 15.000 & Ton & 3,00 \\
\hline \multicolumn{1}{|c|}{ Total } & & & & 51,12 \\
\hline
\end{tabular}

Dari Tabel 1 tersebut terlihat bahwa Camco Omya Indonesia yang memproduksi kalsium karbonat memberikan kontribusi emisi $\mathrm{CO} 2$ paling besar yaitu 48 ton setiap tahunnya.

Tabel 2. Hasil Perhitungan Emisi dari Industri

\begin{tabular}{|c|c|c|c|c|c|c|}
\hline \multirow[b]{2}{*}{$\begin{array}{l}\text { Nama } \\
\text { Industri }\end{array}$} & \multicolumn{3}{|c|}{ Emisi } & \multicolumn{3}{|c|}{ Ambien } \\
\hline & $\begin{array}{c}\text { Parame } \\
\text { ter } \\
\text { Domina } \\
\mathbf{n}\end{array}$ & $\begin{array}{l}\text { Nilai } \\
\text { Ukur }\end{array}$ & $\begin{array}{c}\text { satua } \\
\mathbf{n}\end{array}$ & $\begin{array}{c}\text { Parame } \\
\text { ter } \\
\text { Domina } \\
\text { n }\end{array}$ & $\begin{array}{l}\text { Nilai } \\
\text { ukur }\end{array}$ & $\begin{array}{c}\text { Satu } \\
\text { an }\end{array}$ \\
\hline \multirow{4}{*}{$\begin{array}{l}\text { PT. } \\
\text { Semen } \\
\text { Gresik }\end{array}$} & $\mathrm{NO} 2$ & 66,63 & $\begin{array}{l}\mathrm{mg} / \mathrm{m} \\
3\end{array}$ & $\mathrm{CO}$ & $\begin{array}{l}3,569 \\
2\end{array}$ & Ppm \\
\hline & $\mathrm{SO} 2$ & $\begin{array}{l}388,2 \\
4\end{array}$ & $\begin{array}{l}\mathrm{mg} / \mathrm{m} \\
3\end{array}$ & NOx & $\begin{array}{l}0,024 \\
4\end{array}$ & Ppm \\
\hline & Partikel & 5,32 & $\begin{array}{l}\mathrm{mg} / \mathrm{m} \\
3\end{array}$ & $\mathrm{SO} 2$ & $\begin{array}{l}0,004 \\
7 \\
\end{array}$ & Ppm \\
\hline & & & & Debu & $\begin{array}{l}0,101 \\
8\end{array}$ & $\begin{array}{l}\mathrm{mg} / \\
\mathrm{m} 3\end{array}$ \\
\hline
\end{tabular}

Sumber : Bapedal Propinsi Jawa Timur

Tabel 2 menyajikan informasi emisi yang dihasilkan oleh PT. Semen Gresik. Dalam hal ini, emisi terbesar yang dihasilkan adalah $\mathrm{SO}_{2}$ sebanyak $388 \mathrm{mg} / \mathrm{m}^{3}$.

Tabel 3. Baku Mutu Emisi untuk Industri Semen

\begin{tabular}{|l|l|l|l|}
\hline No & Sumber & Parameter & Baku Mutu (mg/Nm3) \\
\hline 1 & Penanganan Bahan Baku & Total partikel (debu) & 230 \\
\hline 2 & Tanur putar (KILNS) & $\begin{array}{l}\text { Total partikel (debu) Sulfur } \\
\text { Dioksida ( SO2) Nitrogen } \\
\text { Dioksida (NO2) Opasitas }\end{array}$ & $80800100020 \%$ \\
\hline 3 & Pendingin Terak (Clinker Coolers) & Total partikel (debu) & 80 \\
\hline 4 & $\begin{array}{l}\text { Milling Grinding Alat Pengangkut } \\
\text { (Conveying) Pengepakan (Bagging) }\end{array}$ & Total partikel (debu) & 80 \\
\hline 5 & $\begin{array}{l}\text { Utilitas Mengacu pada ketel uap, } \\
\text { berbahan bakayang sesuai }\end{array}$ & $\begin{array}{l}\text { Menyesuaikan dengan bahan } \\
\text { bakar ketel }\end{array}$ & \\
\hline
\end{tabular}

Sumber : Peraturan Gubernur Jawa Timur No. 39, 2008.
Tabel 3 menyajikan informasi tentang baku mutu emisi untuk industri semen. Dengan membandingkan nilai emisi dan ambien antara Tabel 2 dan Tabel 3, maka dapat diketahui bahwa emisi yang dihasilkan oleh beberapa PT. Semen Gresik masih berada di bawah ambang batas yang diperbolehkan.

Tabel 4. Hasil Perhitungan Emisi dari Industri Kimia

\begin{tabular}{|c|c|c|c|c|c|c|}
\hline Nama & Produk & Produksi & Satuan & SF6 & PFCS & HCFs \\
\hline $\begin{array}{l}\text { PT. } \\
\text { INDHOPERIN } \\
\text { JAYA }\end{array}$ & $\begin{array}{l}\text { - RESIN } \\
\text { PHENOL }\end{array}$ & 5000 & Ton & 0,24 & 0,20 & 0,13 \\
\hline $\begin{array}{l}\text { PT. } \\
\text { PAMOLITE } \\
\text { ADHEVISE } \\
\text { INDUSTRI } \\
\text { ( P A I ) }\end{array}$ & $\begin{array}{l}\text { - FORMALIN } \\
\text { paket untuk } \\
\text { Plywood dan } \\
\text { MDF }\end{array}$ & 48000 & Ton & 2,35 & 1,92 & 1,28 \\
\hline $\begin{array}{l}\text { PT. AMAK } \\
\text { FIRDAUS } \\
\text { UTOMO }\end{array}$ & $\begin{array}{l}\text { - FORMALIN } \\
\text { paket untuk } \\
\text { Plywood dan } \\
\text { MDF }\end{array}$ & 48000 & Ton & 2,35 & 1,92 & 1,28 \\
\hline $\begin{array}{l}\text { DAMAR } \\
\text { LANGGENG } \\
\text { UTAMA }\end{array}$ & $\begin{array}{l}\text { Indst. Kimia } \\
\text { Dasar } \\
\text { Organik Yg } \\
\text { Tdk di } \\
\text { Klasifikasikan } \\
\text { di tempat } \\
\text { lainya } \\
\text { (gliserin dan } \\
\text { ester lainnay } \\
\text { (mono alkyl } \\
\text { ester) }\end{array}$ & 3850 & Ton & 0,19 & 0,15 & 0,10 \\
\hline $\begin{array}{l}\text { UNICHEM } \\
\text { CANDI } \\
\text { INDUSTRI }\end{array}$ & $\begin{array}{l}\text { Indst. Kimia } \\
\text { Dasar an } \\
\text { Organik Yg Tdk } \\
\text { diklasifikasikan } \\
\text { di tempat lain } \\
\end{array}$ & 246000 & Ton & 12,02 & 9,83 & 6,56 \\
\hline TPPI & $\begin{array}{l}\text { Pusat olefin : } \\
\text { Methene, } \\
\text { Ethylene, } \\
\text { Propylene, C4 } \\
\text { Component, } \\
\text { Pyrolysis Fuel } \\
\text { Oil } \\
\end{array}$ & 1790000 & Ton & 87,45 & 71,55 & 47,70 \\
\hline $\begin{array}{l}\text { REXINK } \\
\text { INDONESIA } \\
\end{array}$ & Tinta tulis & 600 & Ton & 0,03 & 0,02 & 0,02 \\
\hline $\begin{array}{l}\text { ANEKA KIMIA } \\
\text { UNIT PABRIK } \\
\text { ETANOL }\end{array}$ & Ethanol & 110083 & Ton & 5,38 & 4,40 & 2,93 \\
\hline Total & & 2251533 & & 110 & 90 & 60 \\
\hline
\end{tabular}


Tabel 4 menampilkan hasil perhitungan emisi GRK yang besumber dari industri kimia. Dari Tabel 4 dapat diketahui bahwa TTPI memproduksi SF6, PFC5, dan HCFs terbesar.

Tabel 5. Hasil Perhitungan Emisi dari Industri Logam

\begin{tabular}{|c|c|c|c|c|c|c|}
\hline \multirow[b]{2}{*}{$\begin{array}{l}\text { Nama } \\
\text { Industri }\end{array}$} & \multicolumn{3}{|c|}{ Emisi } & \multicolumn{3}{|c|}{ Ambien } \\
\hline & $\begin{array}{l}\text { Para } \\
\text { met } \\
\text { er } \\
\text { Dom } \\
\text { inan }\end{array}$ & $\begin{array}{l}\text { Nilai } \\
\text { Ukur }\end{array}$ & sat & $\begin{array}{c}\text { Parame } \\
\text { ter } \\
\text { Domina } \\
n\end{array}$ & $\begin{array}{l}\text { Nilai } \\
\text { ukur }\end{array}$ & sat \\
\hline \multicolumn{7}{|l|}{ Gresik } \\
\hline $\begin{array}{l}\text { PT. } \\
\text { Smelting }\end{array}$ & \multicolumn{3}{|c|}{ N/A } & \multicolumn{3}{|c|}{ N/A } \\
\hline \multicolumn{7}{|l|}{ Sidoarjo } \\
\hline \multirow[t]{4}{*}{$\begin{array}{l}\text { PT. } \\
\text { Ispatind } \\
\text { o }\end{array}$} & $\mathrm{NO} 2$ & 0,886 & $\mathrm{mg} / \mathrm{m}$ & $\mathrm{CO}$ & 1,16 & ppm \\
\hline & $\mathrm{SO} 2$ & & & $\mathrm{SO} 2$ & 0.041 & ppm \\
\hline & $\begin{array}{l}\text { Parti } \\
\text { kel }\end{array}$ & 27.39 & $\begin{array}{l}\mathrm{Mg} / \mathrm{m} \\
3\end{array}$ & NOx & 0.052 & ppm \\
\hline & & & & Debu & 0.14 & $\begin{array}{l}\mathrm{mg} / \\
\mathrm{m} 3\end{array}$ \\
\hline \multirow[t]{4}{*}{$\begin{array}{l}\text { CV. } \\
\text { Hanil } \\
\text { Jaya } \\
\end{array}$} & $\mathrm{NO} 2$ & 1.02 & $\mathrm{mg} / \mathrm{m}$ & $\mathrm{CO}$ & & ppm \\
\hline & $\mathrm{SO} 2$ & 13.9 & $\begin{array}{l}\mathrm{mg} / \mathrm{m} \\
3\end{array}$ & $\mathrm{SO} 2$ & 0.005 & ppm \\
\hline & $\begin{array}{l}\text { Parti } \\
\text { kel }\end{array}$ & 18.03 & $\mathrm{mg} / \mathrm{m}$ & NOx & 0.01 & ppm \\
\hline & & & & Debu & 0.12 & $\begin{array}{l}\mathrm{mg} / \\
\mathrm{m} 3\end{array}$ \\
\hline \multicolumn{7}{|c|}{$\begin{array}{l}\text { Mojokerto (15 industri peleburan/pengolahan logam di } \\
\text { kawasan Ngoro Industri Persada) }\end{array}$} \\
\hline \multirow[t]{4}{*}{$\begin{array}{l}\text { PT } \\
\text { Ngoro } \\
\text { Industri }\end{array}$} & & N/A & & $\mathrm{CO}$ & $<\mathrm{LD}$ & ppm \\
\hline & & & & NOx & 0,007 & $\mathrm{ppm}$ \\
\hline & & & & 502 & 0,008 & ppm \\
\hline & & & & Debu & 0,479 & $\begin{array}{l}\mathrm{mg} / \\
\mathrm{m} 3\end{array}$ \\
\hline
\end{tabular}

Tabel 5 merupakan hasil perhitungan emisi GRK yang berasal dari industri logam. Dari Tabel 5 tersebut dapat diketahui bahwa PT. Ispatindo memproduksi partikel terbesar yaitu $27,39 \mathrm{mg} / \mathrm{m}^{3}$, sedangkan $\mathrm{CV}$ Hanil Jaya menghasilkan $\mathrm{NO}_{2}$ dan $\mathrm{SO}_{2}$ paling banyak yaitu 1,02 dan $13,9 \mathrm{mg} / \mathrm{m}^{3}$.

Tabel 6. Baku Mutu Emisi Untuk Industri Logam dan Sejenisnya

\begin{tabular}{l|l|l|l|}
\hline 0 & Sumber & Parameter & Baku Mutu (mg/Nm3) \\
\hline & Penanganan Bahan Baku & Total partikel & 150 \\
\hline & Proses peleburan & $\begin{array}{l}\text { Total partikel (debu) Sulfur Dioksida } \\
\text { (SO2) Nitrogen Dioksida (NO2) }\end{array}$ & 15010001200 \\
\hline & $\begin{array}{l}\text { Proses khusus a. Mekanik b. } \\
\text { Anneling c. Lapis metal + HCL d. } \\
\text { Lapis listrik e. Pengecatan }\end{array}$ & $\begin{array}{l}\text { Total partkel (debu) Total partikel } \\
\text { (debu) Total partkel (debu) Total } \\
\text { partikel (debu) Total partikel (debu) }\end{array}$ & $\begin{array}{l}150150150150 \\
150\end{array}$ \\
\hline & $\begin{array}{l}\text { Utilitas Mengacu pada ketel uap. } \\
\text { berbahan bakaryang sesuai }\end{array}$ & $\begin{array}{l}\text { Menyesuaikan dengan bahan bakar } \\
\text { ketel }\end{array}$ & \\
\hline & Semua sumber & Opasitas & $20 \%$ \\
\hline
\end{tabular}

Tabel 6 merupakan Baku Mutu Emisi untuk industri logam. Dengan membandingkan nilai-nilai yang terdapat di dalam Tabel 5 dan Tabel 6, dapat diketahui bahwa beberapa komponen yang ada masih berada di bawah ambang atas.

Tabel 7 dan 8 merupakan hasil perhitungan emisi GRK yang berasal dari industri kertas dan pulp di beberapa kota.

Tabel 7. Hasil Perhitungan Emisi dari Pulp dan Kertas

\begin{tabular}{|c|c|c|c|c|c|c|}
\hline \multirow[b]{2}{*}{$\begin{array}{l}\text { Nama } \\
\text { Industri }\end{array}$} & \multicolumn{3}{|c|}{ Emisi } & \multicolumn{3}{|c|}{ Ambien } \\
\hline & $\begin{array}{l}\text { Parameter } \\
\text { Dominan }\end{array}$ & $\begin{array}{l}\text { Nilai } \\
\text { Ukur }\end{array}$ & satuan & $\begin{array}{c}\text { Paramet } \\
\text { er } \\
\text { Dominan }\end{array}$ & $\begin{array}{l}\text { Nilai } \\
\text { ukur }\end{array}$ & Satuan \\
\hline \multicolumn{7}{|c|}{ Surabaya } \\
\hline \multirow[t]{4}{*}{$\begin{array}{l}\text { PT } \\
\text { Suparm } \\
\text { a Tbk }\end{array}$} & & & & $\mathrm{CO}$ & $<\mathrm{LD}$ & $\mathrm{ppm}$ \\
\hline & $\mathrm{SO} 2$ & 842 & $\mathrm{mg} / \mathrm{m} 3$ & NOx & 0,0033 & $\mathrm{ppm}$ \\
\hline & Partikel & 148 & $\mathrm{mg} / \mathrm{m} 3$ & $\mathrm{SO} 2$ & 0,0098 & $\mathrm{ppm}$ \\
\hline & NO2 & 356 & $\mathrm{mg} / \mathrm{m} 3$ & Debu & 0,053 & $\begin{array}{l}\mathrm{mg} / \mathrm{m} \\
3\end{array}$ \\
\hline \multicolumn{7}{|l|}{ Gresik } \\
\hline \multirow[t]{3}{*}{$\begin{array}{l}\text { Surya } \\
\text { Agung } \\
\text { Kertas } \\
\end{array}$} & $\mathrm{NO2}$ & 22,97 & $\mathrm{mg} / \mathrm{m} 3$ & & & \\
\hline & $\mathrm{SO} 2$ & 26,54 & $\mathrm{mg} / \mathrm{m} 3$ & & & \\
\hline & Partikel & 2449,6 & $\mathrm{mg} / \mathrm{m} 3$ & & & \\
\hline \multirow[t]{4}{*}{$\begin{array}{l}\text { Sby } \\
\text { Mekabo } \\
x\end{array}$} & $\mathrm{NO2}$ & 9,214 & $\mathrm{mg} / \mathrm{m} 3$ & $\mathrm{CO}$ & 0,0802 & $\mathrm{ppm}$ \\
\hline & $\mathrm{SO2}$ & $<\mathrm{LD}$ & $\mathrm{mg} / \mathrm{m} 3$ & NOx & 0,0103 & $\mathrm{ppm}$ \\
\hline & Partikel & 241,41 & $\mathrm{mg} / \mathrm{m} 3$ & $\mathrm{SO} 2$ & $<\mathrm{LD}$ & $\mathrm{ppm}$ \\
\hline & & & & Debu & 0,1299 & $\begin{array}{l}\mathrm{mg} / \mathrm{m} \\
3\end{array}$ \\
\hline \multicolumn{7}{|c|}{ Mojokerto } \\
\hline $\begin{array}{l}\text { PT } \\
\text { Pakerin }\end{array}$ & NO2 & 0,651 & $\mathrm{mg} / \mathrm{m} 3$ & $\mathrm{CO}$ & 0,7292 & $\mathrm{ppm}$ \\
\hline & $\mathrm{SO2}$ & 0,1333 & $\mathrm{mg} / \mathrm{m} 3$ & NOx & 0,0542 & $\mathrm{ppm}$ \\
\hline & Partikel & 95,038 & $\mathrm{mg} / \mathrm{m} 3$ & $\mathrm{SO} 2$ & 0,0024 & $\mathrm{ppm}$ \\
\hline & & & & Debu & 0,0565 & $\begin{array}{l}\mathrm{mg} / \mathrm{m} \\
3\end{array}$ \\
\hline
\end{tabular}




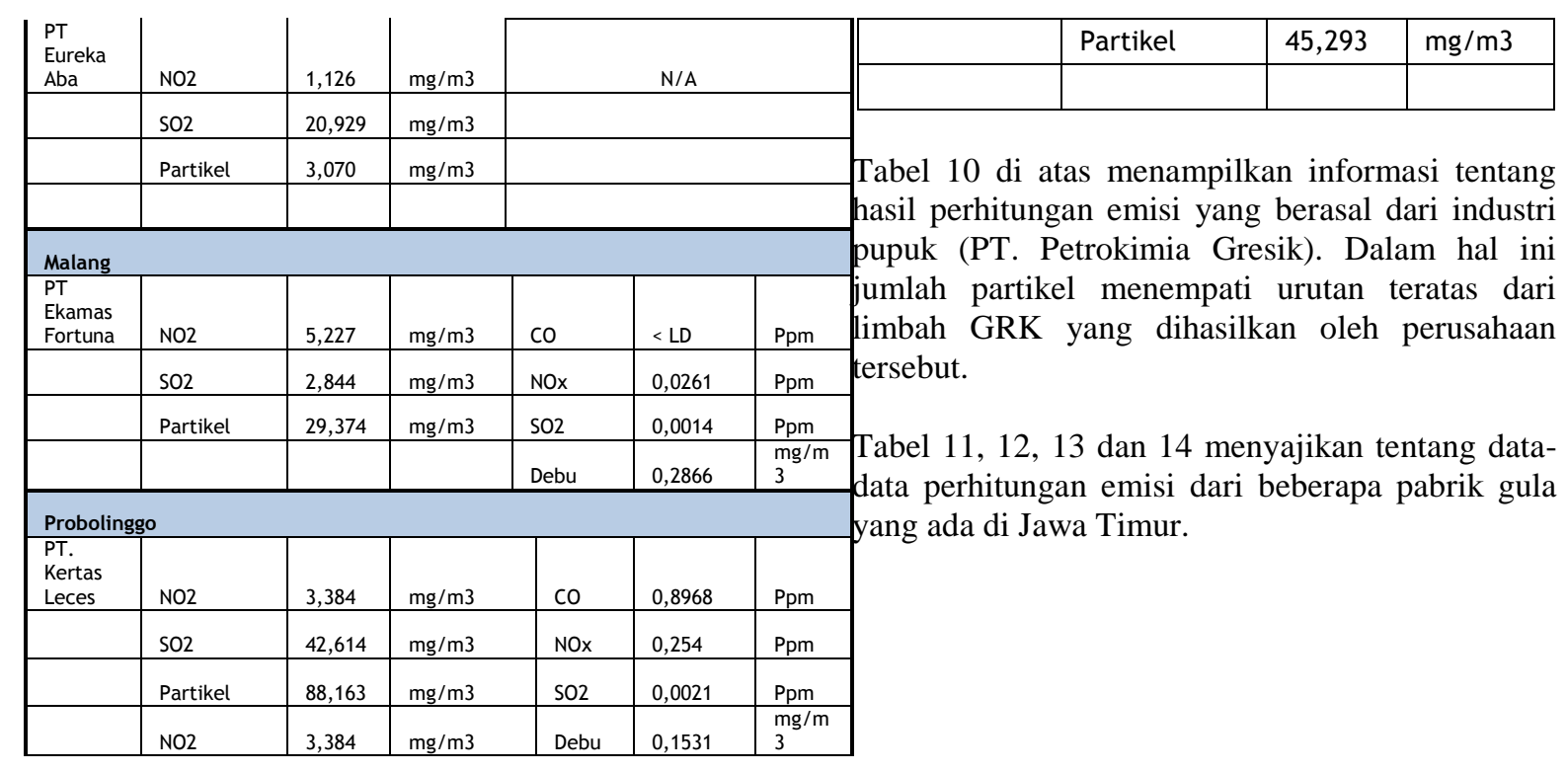

Tabel 8. Lanjutan Hasil Perhitungan Emisi dari Pulp dan Kertas

\begin{tabular}{|c|c|c|c|c|c|c|}
\hline \multirow[b]{2}{*}{$\begin{array}{c}\text { Nama } \\
\text { Industri }\end{array}$} & \multicolumn{2}{|c|}{ Emisi } & \multicolumn{4}{|c|}{ Ambien } \\
\hline & $\begin{array}{c}\text { Para } \\
\text { met } \\
\text { er } \\
\text { Dom } \\
\text { inan }\end{array}$ & $\begin{array}{l}\text { Nilai } \\
\text { Ukur }\end{array}$ & $\begin{array}{c}\text { satu } \\
\text { an }\end{array}$ & $\begin{array}{l}\text { Parameter } \\
\text { Dominan }\end{array}$ & $\begin{array}{l}\text { Nilai } \\
\text { ukur }\end{array}$ & $\begin{array}{c}\text { Satu } \\
\text { an }\end{array}$ \\
\hline \multicolumn{7}{|c|}{ Tulungagung } \\
\hline \multirow[t]{4}{*}{$\begin{array}{l}\text { PT. Setia } \\
\text { Kawan }\end{array}$} & NO2 & 8,119 & $\begin{array}{l}\mathrm{mg} / \\
\mathrm{m} 3\end{array}$ & $\mathrm{CO}$ & $\begin{array}{l}0,05 \\
65\end{array}$ & $\mathrm{Ppm}$ \\
\hline & SO2 & 19,306 & $\begin{array}{l}\mathrm{mg} / \\
\mathrm{m} 3\end{array}$ & NOx & $\begin{array}{l}0,01 \\
26\end{array}$ & $\mathrm{Ppm}$ \\
\hline & $\begin{array}{l}\text { Part } \\
\text { ikel }\end{array}$ & 58,872 & $\begin{array}{l}\mathrm{mg} / \\
\mathrm{m} 3\end{array}$ & SO2 & $\begin{array}{l}0,02 \\
04\end{array}$ & $\mathrm{Ppm}$ \\
\hline & & & & Debu & $\begin{array}{l}0,48 \\
06\end{array}$ & $\begin{array}{l}\mathrm{mg} / \\
\mathrm{m} 3\end{array}$ \\
\hline \multicolumn{7}{|c|}{ Banyuwangi } \\
\hline \multirow{5}{*}{$\begin{array}{l}\text { PT. } \\
\text { Kertas } \\
\text { Basuki } \\
\text { Rahmat } \\
\end{array}$} & NO2 & 7,702 & $\begin{array}{l}\mathrm{mg} / \\
\mathrm{m} 3\end{array}$ & $\mathrm{CO}$ & $\begin{array}{l}0,29 \\
7\end{array}$ & $\mathrm{Ppm}$ \\
\hline & $\mathrm{SO} 2$ & 10,84 & $\begin{array}{l}\mathrm{mg} / \\
\mathrm{m} 3\end{array}$ & NOx & 0,02 & Ppm \\
\hline & $\begin{array}{l}\text { Tota } \\
\text { I } \\
\text { Part } \\
\text { ikel }\end{array}$ & 22,74 & $\begin{array}{l}\mathrm{mg} / \\
\mathrm{m} 3\end{array}$ & SO2 & $\begin{array}{l}0,00 \\
37\end{array}$ & $\mathrm{Ppm}$ \\
\hline & & & & Debu & $\begin{array}{l}0,28 \\
5\end{array}$ & $\begin{array}{l}\mathrm{mg} / \\
\mathrm{m} 3\end{array}$ \\
\hline & & & & & & \\
\hline
\end{tabular}

Adapun Peraturan Gubernur Jatim No. 39 Tahun 2008 mensyaratkan baku mutu emisi Industri pulp dan kertas di Propinsi Jawa Timur sebagaimana dapat dilihat pada Tabel 9 berikut ini.

Tabel 10. Hasil Perhitungan Emisi dari Industri Pupuk

\begin{tabular}{|c|c|c|c|}
\hline \multirow{2}{*}{$\begin{array}{c}\text { Nama } \\
\text { Industri }\end{array}$} & \multicolumn{3}{|c|}{ Emisi } \\
\hline & $\begin{array}{c}\text { Parameter } \\
\text { Dominan }\end{array}$ & $\begin{array}{l}\text { Nilai } \\
\text { Ukur }\end{array}$ & satuan \\
\hline \multicolumn{4}{|l|}{ Gresik } \\
\hline \multirow{2}{*}{$\begin{array}{l}\text { Petrokimia } \\
\text { Gresik }\end{array}$} & NO2 & 1,419 & $\mathrm{mg} / \mathrm{m} 3$ \\
\hline & SO2 & 61,411 & $\mathrm{mg} / \mathrm{m} 3$ \\
\hline
\end{tabular}

Tabel 11. Hasil Perhitungan Emisi dari Industri

\begin{tabular}{|c|c|c|c|c|c|c|}
\hline \multirow[b]{2}{*}{$\begin{array}{c}\text { Nama } \\
\text { Industri }\end{array}$} & \multicolumn{3}{|c|}{ Emisi } & \multicolumn{3}{|c|}{ Ambien } \\
\hline & $\begin{array}{c}\text { Para } \\
\text { meter } \\
\text { Domi } \\
\text { nan }\end{array}$ & $\begin{array}{l}\text { Nilai } \\
\text { Ukur }\end{array}$ & $\begin{array}{l}\text { Sat } \\
\text { uan }\end{array}$ & $\begin{array}{c}\text { Para } \\
\text { meter } \\
\text { Domi } \\
\text { nan }\end{array}$ & $\begin{array}{l}\text { Nilai } \\
\text { ukur }\end{array}$ & $\begin{array}{l}\text { Sat } \\
\text { uan }\end{array}$ \\
\hline \multicolumn{7}{|l|}{ Kediri } \\
\hline \multirow[t]{4}{*}{$\begin{array}{l}\text { PG } \\
\text { Pesantre } \\
n\end{array}$} & $\mathrm{NO}_{2}$ & 10,498 & $\underset{/ \mathrm{m}^{3}}{\mathrm{mg}}$ & $\mathrm{CO}$ & $\begin{array}{l}1,163 \\
5\end{array}$ & $\begin{array}{l}\mathrm{pp} \\
\mathrm{m}\end{array}$ \\
\hline & $\mathrm{SO}_{2}$ & 27,608 & $\mathrm{mg}$ & NOx & $\begin{array}{l}0,023 \\
0\end{array}$ & $\begin{array}{l}\mathrm{pp} \\
\mathrm{m}\end{array}$ \\
\hline & $\begin{array}{l}\text { Total } \\
\text { Partik } \\
\text { el }\end{array}$ & 84,104 & $\begin{array}{l}\mathrm{mg} \\
/ \mathrm{m}^{3}\end{array}$ & $\mathrm{SO}_{2}$ & $\begin{array}{l}0,005 \\
4\end{array}$ & $\begin{array}{l}\mathrm{pp} \\
\mathrm{m}\end{array}$ \\
\hline & & & & Debu & - & $\begin{array}{l}\mathrm{mg} \\
/ \mathrm{m}^{3}\end{array}$ \\
\hline \multirow[t]{4}{*}{$\begin{array}{l}\text { PG } \\
\text { Ngadirej } \\
\text { o }\end{array}$} & $\mathrm{NO}_{2}$ & 12,661 & $\begin{array}{l}\mathrm{mg} \\
/ \mathrm{m}^{3}\end{array}$ & $\mathrm{CO}$ & $\begin{array}{l}4,480 \\
2\end{array}$ & $\begin{array}{l}\mathrm{pp} \\
\mathrm{m}\end{array}$ \\
\hline & $\mathrm{SO}_{2}$ & 4,253 & $\begin{array}{l}\mathrm{mg} \\
/ \mathrm{m}^{3}\end{array}$ & $\mathrm{NO}_{\mathrm{x}}$ & $\begin{array}{l}0,023 \\
2\end{array}$ & $\begin{array}{l}\mathrm{pp} \\
\mathrm{m}\end{array}$ \\
\hline & $\begin{array}{l}\text { Partik } \\
\text { el }\end{array}$ & 200,451 & $\begin{array}{l}\mathrm{mg} \\
/ \mathrm{m}^{3}\end{array}$ & $\mathrm{SO}_{2}$ & $\begin{array}{l}0,002 \\
8\end{array}$ & $\begin{array}{l}\mathrm{pp} \\
\mathrm{m}\end{array}$ \\
\hline & & & & Debu & $\begin{array}{l}0,101 \\
3\end{array}$ & $\begin{array}{l}\mathrm{mg} \\
/ \mathrm{m}^{3}\end{array}$ \\
\hline \multicolumn{7}{|l|}{ Jember } \\
\hline \multirow[t]{4}{*}{$\begin{array}{l}\text { PG } \\
\text { Semboro }\end{array}$} & $\mathrm{NO}_{2}$ & 2,634 & $\begin{array}{l}\mathrm{mg} \\
/ \mathrm{m}^{3}\end{array}$ & $\mathrm{CO}$ & $\begin{array}{l}1,243 \\
4\end{array}$ & $\begin{array}{l}\mathrm{pp} \\
\mathrm{m}\end{array}$ \\
\hline & $\mathrm{SO2}$ & 20,284 & $\begin{array}{l}\mathrm{mg} \\
/ \mathrm{m}^{3}\end{array}$ & $\mathrm{NO}_{\mathrm{x}}$ & $\begin{array}{l}0,011 \\
5\end{array}$ & $\begin{array}{l}\mathrm{pp} \\
\mathrm{m}\end{array}$ \\
\hline & $\begin{array}{l}\text { Total } \\
\text { Partik } \\
\text { el }\end{array}$ & 187,152 & $\begin{array}{l}\mathrm{mg} \\
\mathrm{mg} \\
3\end{array}$ & SO2 & $\begin{array}{l}0,002 \\
8\end{array}$ & $\begin{array}{l}\mathrm{pp} \\
\mathrm{m}\end{array}$ \\
\hline & & & & Debu & & $\begin{array}{l}\mathrm{mg} \\
/ \mathrm{m} \\
3\end{array}$ \\
\hline \multicolumn{7}{|l|}{ Sidoarjo } \\
\hline $\begin{array}{l}\text { PG } \\
\text { Watutuli } \\
\mathrm{s}\end{array}$ & NO2 & 2,634 & $\begin{array}{l}\mathrm{mg} / \\
\mathrm{m} 3\end{array}$ & CO & $\begin{array}{l}1,243 \\
4\end{array}$ & $\begin{array}{l}\mathrm{pp} \\
\mathrm{m}\end{array}$ \\
\hline & SO2 & 20,284 & $\begin{array}{l}\mathrm{mg} / \\
\mathrm{m} 3\end{array}$ & NOx & $\begin{array}{l}0,011 \\
5\end{array}$ & $\begin{array}{l}\mathrm{pp} \\
\mathrm{m}\end{array}$ \\
\hline & $\begin{array}{l}\text { Total } \\
\text { Partik } \\
\text { el }\end{array}$ & 187,152 & $\begin{array}{l}\mathrm{mg} / \\
\mathrm{m} 3\end{array}$ & SO2 & $\begin{array}{l}0,002 \\
8\end{array}$ & $\begin{array}{l}\mathrm{pp} \\
\mathrm{m}\end{array}$ \\
\hline
\end{tabular}




\begin{tabular}{|c|c|c|c|c|c|c|}
\hline & & & & $\begin{array}{l}\text { Deb } \\
\text { u }\end{array}$ & & $\begin{array}{l}\mathrm{mg} \\
/ \mathrm{m} \\
3\end{array}$ \\
\hline \multirow{4}{*}{$\begin{array}{l}\text { PG Candi } \\
\text { Baru }\end{array}$} & NO2 & 46,32 & $\begin{array}{l}\mathrm{mg} / \\
\mathrm{m} 3\end{array}$ & $\mathrm{CO}$ & 0,85 & $\begin{array}{l}\mathrm{pp} \\
\mathrm{m}\end{array}$ \\
\hline & SO2 & 22,19 & $\begin{array}{l}\mathrm{mg} / \\
\mathrm{m} 3\end{array}$ & NOx & $\begin{array}{l}0,001 \\
7\end{array}$ & $\begin{array}{l}\mathrm{pp} \\
\mathrm{m}\end{array}$ \\
\hline & $\begin{array}{l}\text { Total } \\
\text { Partik } \\
\text { el }\end{array}$ & 186,20 & $\begin{array}{l}\mathrm{mg} / \\
\mathrm{m} 3\end{array}$ & $\mathrm{SO} 2$ & $\begin{array}{l}0,005 \\
2\end{array}$ & $\begin{array}{l}\mathrm{pp} \\
\mathrm{m}\end{array}$ \\
\hline & & & & $\begin{array}{l}\text { Deb } \\
\text { u }\end{array}$ & 0,154 & $\begin{array}{l}\mathrm{mg} \\
/ \mathrm{m} \\
3\end{array}$ \\
\hline \multirow[t]{4}{*}{$\begin{array}{l}\text { PG } \\
\text { Toelanga } \\
\mathrm{n}\end{array}$} & $\mathrm{NO2}$ & 9,358 & $\begin{array}{l}\mathrm{mg} / \\
\mathrm{m} 3\end{array}$ & $\mathrm{CO}$ & $\begin{array}{l}0,442 \\
9\end{array}$ & $\begin{array}{l}\mathrm{pp} \\
\mathrm{m}\end{array}$ \\
\hline & $\mathrm{SO} 2$ & $<\mathrm{LD}$ & $\begin{array}{l}\mathrm{mg} / \\
\mathrm{m} 3\end{array}$ & NOx & 0,035 & $\begin{array}{l}\mathrm{pp} \\
\mathrm{m}\end{array}$ \\
\hline & $\begin{array}{l}\text { Total } \\
\text { Partik } \\
\text { el }\end{array}$ & 288,430 & $\begin{array}{l}\mathrm{mg} / \\
\mathrm{m} 3\end{array}$ & $\mathrm{SO2}$ & $\begin{array}{l}0,002 \\
8\end{array}$ & $\begin{array}{l}\mathrm{pp} \\
\mathrm{m}\end{array}$ \\
\hline & & & & $\begin{array}{l}\text { Deb } \\
\text { u }\end{array}$ & $\begin{array}{l}0,198 \\
5\end{array}$ & $\begin{array}{l}\mathrm{mg} \\
/ \mathrm{m} \\
3\end{array}$ \\
\hline
\end{tabular}

\begin{tabular}{|c|c|c|c|c|c|c|}
\hline \multicolumn{7}{|l|}{0} \\
\hline & $\mathrm{SO} 2$ & $\begin{array}{l}9,90 \\
30 \\
\end{array}$ & $\begin{array}{l}\mathrm{mg} / \\
\mathrm{m} 3\end{array}$ & NOx & 0,0228 & $\mathrm{ppm}$ \\
\hline & $\begin{array}{l}\text { Total } \\
\text { Partike } \\
\text { I }\end{array}$ & $\begin{array}{l}108, \\
104\end{array}$ & $\begin{array}{l}\mathrm{mg} / \\
\mathrm{m} 3\end{array}$ & $\mathrm{SO} 2$ & 0,0012 & $\mathrm{ppm}$ \\
\hline & & & & Debu & - & $\begin{array}{l}\mathrm{mg} / \\
\mathrm{m} 3\end{array}$ \\
\hline \multicolumn{7}{|l|}{ Kediri } \\
\hline $\begin{array}{l}\text { PG } \\
\text { Meritja } \\
n\end{array}$ & $\mathrm{NO2}$ & $\begin{array}{l}29,3 \\
45\end{array}$ & $\begin{array}{l}\mathrm{mg} / \\
\mathrm{m} 3\end{array}$ & $\mathrm{CO}$ & 0,5255 & $\mathrm{ppm}$ \\
\hline & $\mathrm{SO} 2$ & $\begin{array}{l}9,45 \\
8\end{array}$ & $\begin{array}{l}\mathrm{mg} / \\
\mathrm{m} 3\end{array}$ & NOx & 0,0475 & $\mathrm{ppm}$ \\
\hline & $\begin{array}{l}\text { Total } \\
\text { Partike } \\
\text { I }\end{array}$ & $\begin{array}{l}73,1 \\
02\end{array}$ & $\begin{array}{l}\mathrm{mg} / \\
\mathrm{m} 3\end{array}$ & $\mathrm{SO} 2$ & $<\mathrm{LD}$ & $\mathrm{ppm}$ \\
\hline & & & & Debu & - & $\begin{array}{l}\mathrm{mg} / \\
\mathrm{m} 3\end{array}$ \\
\hline \multicolumn{7}{|l|}{ Nganjuk } \\
\hline $\begin{array}{l}\text { PG } \\
\text { Lestari }\end{array}$ & $\mathrm{NO} 2$ & $\begin{array}{l}9,93 \\
2\end{array}$ & $\begin{array}{l}\mathrm{mg} / \\
\mathrm{m} 3\end{array}$ & $\mathrm{CO}$ & 1,0207 & $\mathrm{ppm}$ \\
\hline & $\mathrm{SO} 2$ & $\begin{array}{l}22,6 \\
15 \\
\end{array}$ & $\begin{array}{l}\mathrm{mg} / \\
\mathrm{m} 3\end{array}$ & NOx & 0,0242 & $\mathrm{ppm}$ \\
\hline & $\begin{array}{l}\text { Total } \\
\text { Partike } \\
\text { l }\end{array}$ & $\begin{array}{l}125, \\
817\end{array}$ & $\begin{array}{l}\mathrm{mg} / \\
\mathrm{m} 3\end{array}$ & $\mathrm{SO} 2$ & 0,0033 & $\mathrm{ppm}$ \\
\hline & & & & Debu & & $\begin{array}{l}\mathrm{mg} / \\
\mathrm{m} 3\end{array}$ \\
\hline
\end{tabular}

Tabel 12. Lanjutan Hasil Perhitungan Emisi dari Industri Gula

\begin{tabular}{|c|c|c|c|c|c|c|}
\hline \multirow[b]{2}{*}{$\begin{array}{c}\text { Nama } \\
\text { Industr } \\
\mathbf{i}\end{array}$} & \multicolumn{3}{|c|}{ Emisi } & \multicolumn{3}{|c|}{ Ambien } \\
\hline & $\begin{array}{l}\text { Param } \\
\text { eter } \\
\text { Domin } \\
\text { an } \\
\end{array}$ & $\begin{array}{l}\text { Nilai } \\
\text { Ukur }\end{array}$ & $\begin{array}{l}\text { Satu } \\
\text { an }\end{array}$ & $\begin{array}{l}\text { Param } \\
\text { eter } \\
\text { Domin } \\
\text { an } \\
\end{array}$ & $\begin{array}{l}\text { Nilai } \\
\text { ukur }\end{array}$ & $\begin{array}{c}\text { Satu } \\
\text { an }\end{array}$ \\
\hline \multicolumn{7}{|c|}{ Situbondo } \\
\hline \multirow{4}{*}{$\begin{array}{l}\text { PG } \\
\text { Asem } \\
\text { Bagoess }\end{array}$} & NO2 & $\begin{array}{l}2,59 \\
5\end{array}$ & $\begin{array}{l}\mathrm{mg} / \\
\mathrm{m} 3\end{array}$ & $\mathrm{CO}$ & 0,3321 & $\mathrm{ppm}$ \\
\hline & SO2 & $\begin{array}{l}18,9 \\
42\end{array}$ & $\begin{array}{l}\mathrm{mg} / \\
\mathrm{m} 3\end{array}$ & NOx & 0,0573 & $\mathrm{ppm}$ \\
\hline & $\begin{array}{l}\text { Total } \\
\text { Partike } \\
\text { I }\end{array}$ & $\begin{array}{l}174, \\
765\end{array}$ & $\begin{array}{l}\mathrm{mg} / \\
\mathrm{m} 3\end{array}$ & $\mathrm{SO} 2$ & 0,0006 & $\mathrm{ppm}$ \\
\hline & & & & Debu & - & $\begin{array}{l}\mathrm{mg} / \\
\mathrm{m} 3\end{array}$ \\
\hline \multicolumn{7}{|l|}{ Malang } \\
\hline \multirow{4}{*}{$\begin{array}{l}\text { PG } \\
\text { Kebon } \\
\text { Agung }\end{array}$} & NO2 & $\begin{array}{l}66,5 \\
97\end{array}$ & $\begin{array}{l}\mathrm{mg} / \\
\mathrm{m} 3\end{array}$ & $\mathrm{CO}$ & 0,1671 & $\mathrm{ppm}$ \\
\hline & SO2 & $\begin{array}{l}32,7 \\
05\end{array}$ & $\begin{array}{l}\mathrm{mg} / \\
\mathrm{m} 3\end{array}$ & NOx & 0,0133 & $\mathrm{ppm}$ \\
\hline & $\begin{array}{l}\text { Total } \\
\text { Partike } \\
\text { I }\end{array}$ & $\begin{array}{l}388, \\
939\end{array}$ & $\begin{array}{l}\mathrm{mg} / \\
\mathrm{m} 3\end{array}$ & $\mathrm{SO} 2$ & $<\mathrm{LD}$ & $\mathrm{ppm}$ \\
\hline & & & & Debu & - & $\begin{array}{l}\mathrm{mg} / \\
\mathrm{m} 3\end{array}$ \\
\hline \multirow{4}{*}{$\begin{array}{l}\text { PG } \\
\text { Krebet } \\
\text { baru }\end{array}$} & NO2 & $\begin{array}{l}7,01 \\
6\end{array}$ & $\begin{array}{l}\mathrm{mg} / \\
\mathrm{m} 3\end{array}$ & $\mathrm{CO}$ & 2,1915 & $\mathrm{ppm}$ \\
\hline & $\mathrm{SO} 2$ & $\begin{array}{l}117, \\
170\end{array}$ & $\begin{array}{l}\mathrm{mg} / \\
\mathrm{m} 3\end{array}$ & NOx & 0,0432 & $\mathrm{ppm}$ \\
\hline & $\begin{array}{l}\text { Total } \\
\text { Partike } \\
\text { I }\end{array}$ & $\begin{array}{l}1213 \\
, 197\end{array}$ & $\begin{array}{l}\mathrm{mg} / \\
\mathrm{m} 3\end{array}$ & $\mathrm{SO} 2$ & 0,0013 & $\mathrm{ppm}$ \\
\hline & & & & Debu & - & $\begin{array}{l}\mathrm{mg} / \\
\mathrm{m} 3\end{array}$ \\
\hline \multicolumn{7}{|l|}{ Pasuruan } \\
\hline \multirow{4}{*}{$\begin{array}{l}\text { PG } \\
\text { Kedawo } \\
\text { eng }\end{array}$} & NO2 & $\begin{array}{l}1,14 \\
1\end{array}$ & $\begin{array}{l}\mathrm{mg} / \\
\mathrm{m} 3\end{array}$ & $\mathrm{CO}$ & 1,5559 & $\mathrm{ppm}$ \\
\hline & SO2 & $<\mathrm{LD}$ & $\begin{array}{l}\mathrm{mg} / \\
\mathrm{m} 3\end{array}$ & NOx & 0,0202 & $\mathrm{ppm}$ \\
\hline & $\begin{array}{l}\text { Total } \\
\text { Partike } \\
\text { l }\end{array}$ & $\begin{array}{l}\text { 167, } \\
586\end{array}$ & $\begin{array}{l}\mathrm{mg} / \\
\mathrm{m} 3\end{array}$ & $\mathrm{SO} 2$ & 0,0020 & $\mathrm{ppm}$ \\
\hline & & & & Debu & - & $\begin{array}{l}\mathrm{mg} / \mathrm{s} \\
\mathrm{m} 3\end{array}$ \\
\hline \multicolumn{7}{|c|}{ Lumajang } \\
\hline $\begin{array}{l}\mathrm{PG} \\
\text { Jatirot }\end{array}$ & NO2 & $\begin{array}{l}1,93 \\
8\end{array}$ & $\begin{array}{l}\mathrm{mg} / \\
\mathrm{m} 3\end{array}$ & $\mathrm{CO}$ & 1,4917 & $\mathrm{ppm}$ \\
\hline
\end{tabular}

Tabel 13. Lanjutan Hasil Perhitungan Emisi dari Industri Gula

\begin{tabular}{|c|c|c|c|c|c|c|}
\hline \multirow[b]{2}{*}{$\begin{array}{c}\text { Nama } \\
\text { Industri }\end{array}$} & \multicolumn{3}{|c|}{ Emisi } & \multicolumn{3}{|c|}{ Ambien } \\
\hline & $\begin{array}{l}\text { Para } \\
\text { met } \\
\text { er } \\
\text { Dom } \\
\text { inan }\end{array}$ & $\begin{array}{c}\text { Nilai } \\
\text { Uku } \\
r\end{array}$ & $\begin{array}{l}\mathrm{S} \\
\mathrm{a} \\
\mathrm{t} \\
\mathrm{u} \\
\mathrm{a} \\
\mathrm{n} \\
\end{array}$ & $\begin{array}{c}\text { Param } \\
\text { eter } \\
\text { Domina } \\
n\end{array}$ & $\begin{array}{l}\text { Nilai } \\
\text { ukur }\end{array}$ & Satuan \\
\hline \multicolumn{7}{|l|}{ Mojokerto } \\
\hline \multirow{4}{*}{$\begin{array}{l}\text { PG } \\
\text { Gempolkr } \\
\text { ep }\end{array}$} & NO2 & $\begin{array}{l}12,1 \\
89 \\
\end{array}$ & $\begin{array}{l}\mathrm{m} \\
\mathrm{g} \\
1 \\
\mathrm{~m} \\
3 \\
\end{array}$ & $\mathrm{CO}$ & 3,1646 & $\mathrm{ppm}$ \\
\hline & $\mathrm{SO2}$ & $<\mathrm{LD}$ & $\begin{array}{l}\mathrm{m} \\
\mathrm{g} \\
/ \\
\mathrm{m} \\
3 \\
\end{array}$ & NOx & 0,0305 & $\mathrm{ppm}$ \\
\hline & $\begin{array}{l}\text { Part } \\
\text { ikel }\end{array}$ & $\begin{array}{l}121, \\
194\end{array}$ & $\begin{array}{l}\mathrm{m} \\
\mathrm{g} \\
1 \\
\mathrm{~m} \\
3 \\
\end{array}$ & SO2 & $<\mathrm{LD}$ & $\mathrm{ppm}$ \\
\hline & & & & $\begin{array}{l}\text { Deb } \\
\text { u }\end{array}$ & - & $\mathrm{mg} / \mathrm{m} 3$ \\
\hline \multicolumn{7}{|l|}{ Tulungagung } \\
\hline \multirow{4}{*}{$\begin{array}{l}\text { PG } \\
\text { Mojopang } \\
\text { gung }\end{array}$} & $\mathrm{NO2}$ & $\begin{array}{l}7,44 \\
4\end{array}$ & $\begin{array}{l}\mathrm{m} \\
\mathrm{g} \\
\mathrm{j} \\
\mathrm{m} \\
3 \\
\end{array}$ & $\mathrm{CO}$ & 2,3615 & $\mathrm{ppm}$ \\
\hline & $\mathrm{SO} 2$ & $\begin{array}{l}10,4 \\
96\end{array}$ & $\begin{array}{l}\mathrm{m} \\
\mathrm{g} \\
1 \\
\mathrm{~m} \\
3 \\
\end{array}$ & $\begin{array}{l}\text { NO } \\
\mathrm{x}\end{array}$ & 0,0287 & ppm \\
\hline & $\begin{array}{l}\text { Parti } \\
\text { kel }\end{array}$ & $\begin{array}{l}144, \\
891\end{array}$ & $\begin{array}{l}\mathrm{m} \\
\mathrm{g} \\
1 \\
\mathrm{~m} \\
3 \\
\end{array}$ & $\begin{array}{l}\text { so } \\
2\end{array}$ & 0,0003 & $\mathrm{ppm}$ \\
\hline & & & & $\begin{array}{l}\text { De } \\
\text { bu }\end{array}$ & 0,1773 & $\mathrm{mg} / \mathrm{m} 3$ \\
\hline \multicolumn{7}{|l|}{ Madiun } \\
\hline \multirow{2}{*}{$\begin{array}{l}\text { PG Rejo } \\
\text { Agung } \\
\text { Baru }\end{array}$} & NO2 & $\begin{array}{l}18,8 \\
15\end{array}$ & $\begin{array}{l}\mathrm{m} \\
\mathrm{g} \\
1 \\
\mathrm{~m} \\
3 \\
\end{array}$ & $\mathrm{CO}$ & 0,8701 & $\mathrm{ppm}$ \\
\hline & $\mathrm{SO} 2$ & $\begin{array}{l}9,17 \\
3\end{array}$ & $\begin{array}{l}\mathrm{m} \\
\mathrm{g} \\
1 \\
\mathrm{~m} \\
3 \\
\end{array}$ & $\begin{array}{l}\text { NO } \\
x\end{array}$ & 0,0222 & $\mathrm{ppm}$ \\
\hline
\end{tabular}




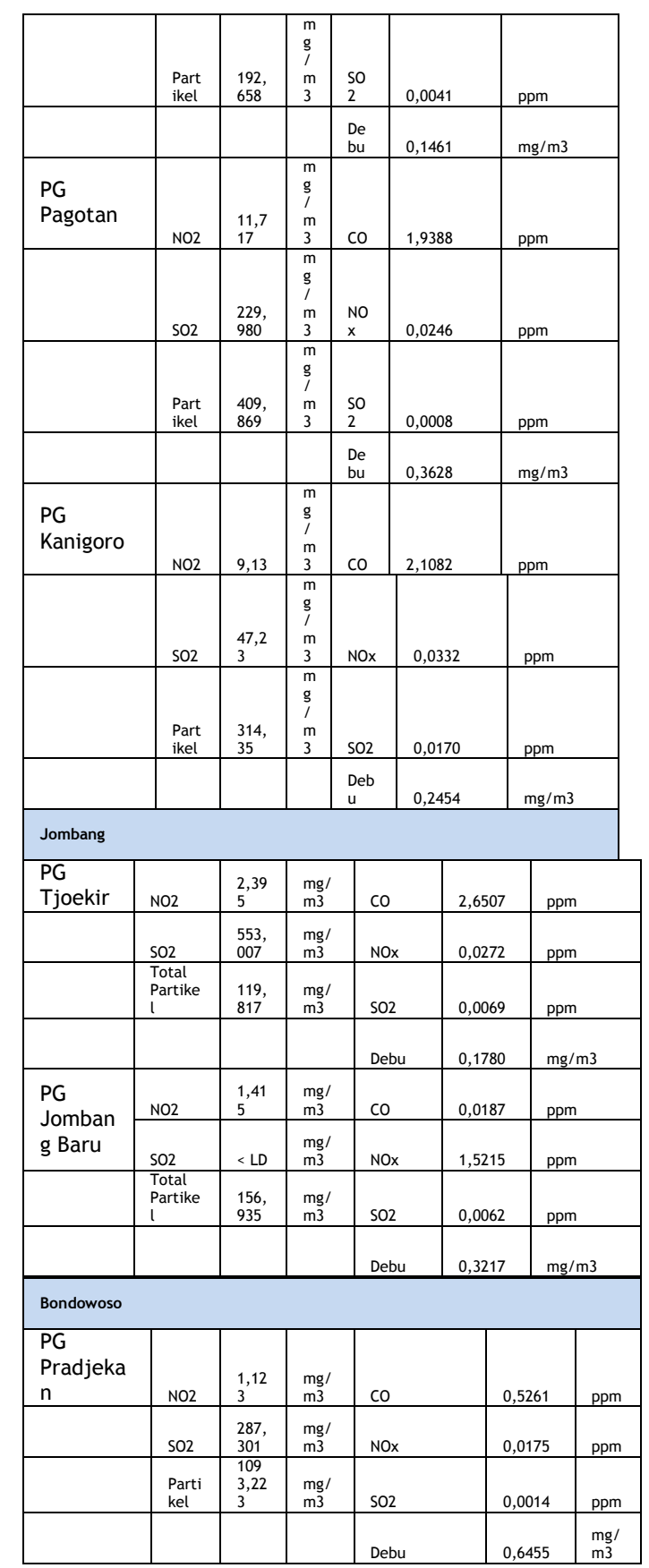

Tabel 14. Lanjutan Hasil Perhitungan Emisi dari Industri Gula

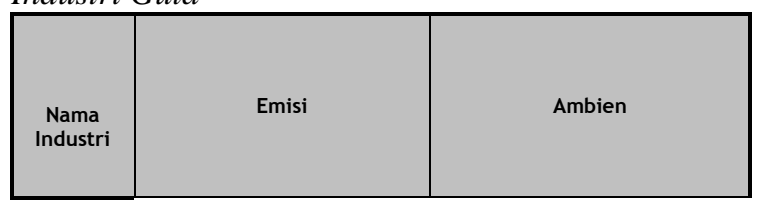

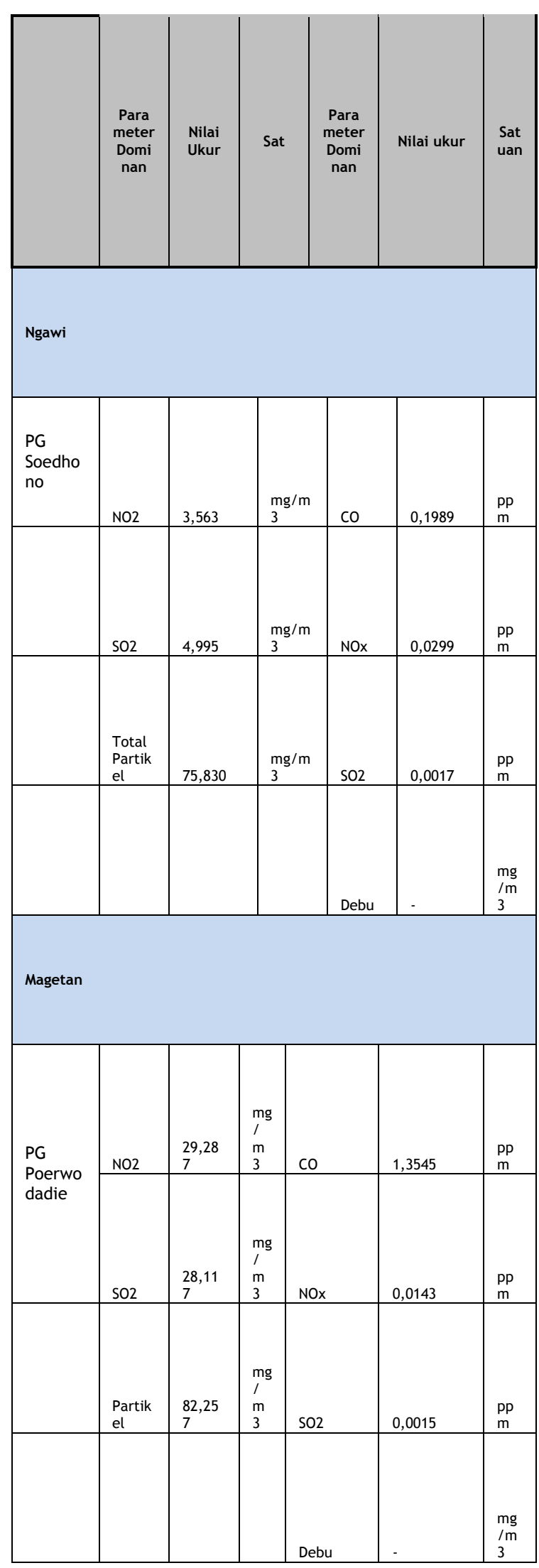




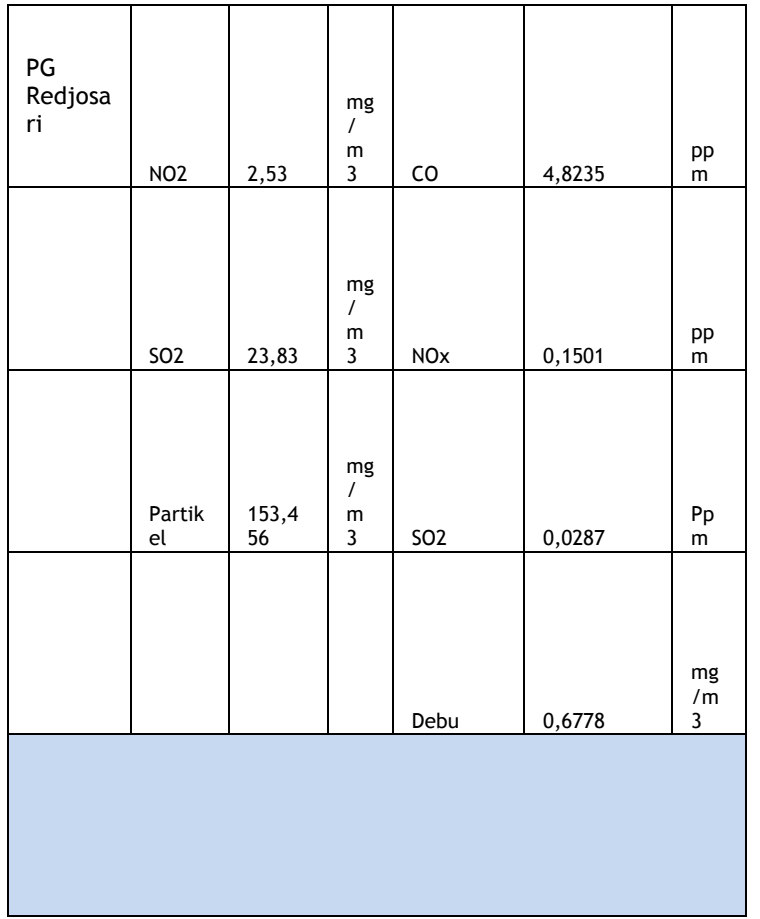

Dari Tabel 11 hingga 14 dapat diketahui bahwa jenis emisi terbanyak yang dihasilkan oleh industri gula adalah partikel. Adapun jumlah $\mathrm{NO}_{2}$ terbanyak diproduksi oleh PG. Kebon Agung yaitu $66,6 \mathrm{mg} / \mathrm{m}^{3}$.

Tabel 15. Baku Mutu Emisi dari Industri Gula

\begin{tabular}{|l|l|l|l|}
\hline No & Sumber & Parameter & Baku Mutu (mg/Nm3) \\
\hline 1. & Sufftasi & Sulur Dioksida ( SO2) & 800 \\
2. & $\begin{array}{l}\text { Uilitas Mengacu pada ketel uap, } \\
\text { berbahan bakaryang sesuai }\end{array}$ & $\begin{array}{l}\text { Menyesuaikan dengan bahan } \\
\text { bakar ketel }\end{array}$ & \\
\hline 3. & Semua sumber lain & Opasitas & $20 \%$ \\
\hline
\end{tabular}

Sumber : Peraturan Gubernur Jawa Timur No. 39, 2008

Tabel 15 menampilkan informasi tentang baku mutu emisi untuk industri gula. Jumla SO2 yang dihasilkan oleh suatu proses produksi tidak boleh melampaui $800 \mathrm{mg} / \mathrm{Nm}^{3}$.

Hasil perhitungan emisi metan $\left(\mathrm{CH}_{4}\right)$ yang berasal dari limbah industri ditampilkan oleh Tabel 16 di bawah ini.

Tabel 16. Hasil Perhitungan Emisi Metan dari Limbah Industri

\begin{tabular}{|c|l|l|c|c|c|}
\hline No & $\begin{array}{c}\text { Nama } \\
\text { Industri }\end{array}$ & Produk & $\begin{array}{c}\text { Kapasi } \\
\text { tas } \\
\text { Produ } \\
\mathbf{k s i}\end{array}$ & $\begin{array}{l}\text { Satua } \\
\mathbf{n}\end{array}$ & $\begin{array}{l}\text { Emisi } \\
\text { CH4 } \\
\text { (Ton } \\
\text { /tahun) }\end{array}$ \\
\hline 1 & $\begin{array}{l}\text { JAVA PAPER } \\
\text { INDO }\end{array}$ & $\begin{array}{l}\text { Bubur } \\
\text { kertas }\end{array}$ & 67.000 & Ton & 1,63 \\
\hline 2 & PAKERIN & Kertas & 345.750 & Ton & 8,40 \\
\hline 3 & $\begin{array}{l}\text { JAVA PAPER } \\
\text { INDO }\end{array}$ & $\begin{array}{l}\text { Bubur } \\
\text { kertas }\end{array}$ & 67.000 & Ton & 1,63 \\
\hline
\end{tabular}

\begin{tabular}{|c|c|c|c|c|c|}
\hline 4 & LIKSAN UTAMA & $\begin{array}{l}\text { Kertas } \\
\text { budaya }\end{array}$ & $\begin{array}{r}1.700 .40 \\
0\end{array}$ & Ton & 41,32 \\
\hline 5 & $\begin{array}{l}\text { SOPANUSA } \\
\text { TISSUE }\end{array}$ & $\begin{array}{l}\text { Kertas } \\
\text { tissue }\end{array}$ & 20.400 & Ton & 0,50 \\
\hline 6 & PAKERIN & Kertas & 345.750 & Ton & 8,40 \\
\hline 7 & EUREKA ABA & $\begin{array}{l}\text { Kertas } \\
\text { karton }\end{array}$ & 21.000 & Ton & 0,51 \\
\hline 8 & Trison Jaya & Kertas & 300 & Ton & 0,01 \\
\hline 9 & Kertas Leces & $\begin{array}{l}\text { Kertas } \\
\text { Tulis } \\
\text { Kertas } \\
\text { Cetak } \\
\text { Kertas } \\
\text { Koran } \\
\text { Kertas } \\
\text { Tisue }\end{array}$ & 160.000 & $\begin{array}{l}\text { Ton } \\
\text { Ton } \\
\text { Ton } \\
\text { Ton }\end{array}$ & 3,89 \\
\hline \multirow{8}{*}{10} & \multirow{8}{*}{ KERTAS LETJES } & \multirow{8}{*}{$\begin{array}{l}- \text { - Lainnya } \\
\text { - Medium } \\
\text { liner } \\
\text { - Kertas } \\
\text { tissue } \\
\text { - Kertas } \\
\text { gambar } \\
\text { - Kertas } \\
\text { koran } \\
\text { - Kertas } \\
\text { HVS } \\
\text { - Kertas } \\
\text { cyclostyle } \\
\text { - Kertas } \\
\text { BC }\end{array}$} & 0 & * & 0,00 \\
\hline & & & 14.475 & Ton & 0,35 \\
\hline & & & 8.655 & Ton & 0,21 \\
\hline & & & 42.680 & Ton & 1,04 \\
\hline & & & 55.168 & Ton & 1,34 \\
\hline & & & 41.659 & Ton & 1,01 \\
\hline & & & 1.830 & Ton & 0,04 \\
\hline & & & 6.009 & Ton & 0,15 \\
\hline 11 & PG. MRICAN & Gula pasir & 39.851 & Ton & 2,48 \\
\hline 12 & $\begin{array}{l}\text { PG. PESANTREN } \\
\text { BARU }\end{array}$ & Gula Pasir & 104.130 & Ton & 6,48 \\
\hline 13 & $\begin{array}{l}\text { PG. } \\
\text { Wonolangan }\end{array}$ & $\begin{array}{l}\text { Gula } \\
\text { Tetes }\end{array}$ & 13.000 & $\begin{array}{l}\text { Ton } \\
\text { Ton }\end{array}$ & 0,81 \\
\hline 14 & PG. Gending & $\begin{array}{l}\text { Gula } \\
\text { Tetes }\end{array}$ & 58.627 & $\begin{array}{l}\text { Ton } \\
\text { Ton } \\
\end{array}$ & 3,65 \\
\hline 15 & PG. Pajarakan & $\begin{array}{l}\text { Gula } \\
\text { Tetes }\end{array}$ & 12.600 & $\begin{array}{l}\text { Ton } \\
\text { Ton }\end{array}$ & 0,78 \\
\hline 16 & 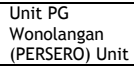 & Gula & 14.188 & Ton & 0,88 \\
\hline 17 & $\begin{array}{l}\text { Unit PG } \\
\text { Gending } \\
\text { (PERSERO) Unit }\end{array}$ & Gula & 143 & Ton & 0,01 \\
\hline 18 & $\begin{array}{l}\text { Unit PG } \\
\text { Pajarakan } \\
\text { (PERSERO) Unit }\end{array}$ & Gula & 125 & Ton & 0,01 \\
\hline & & Total & & & 85,52 \\
\hline
\end{tabular}

Dari tabel 16 di atas dapat dilihat bahwa industri yang menghasilkan metan terbanyak adalah PT. Liksan Utama yang memproduksi ketas budaya. Ia memproduksi limbah $\mathrm{CH} 4$ sebesar 41 ton dalam setiap tahunnya.

\section{Pembahasan}

Sumber emisi Gas Rumah Kaca yang berasal dari industri manufaktur apabila diringkas dalam bentuk tabel dinyatakan oleh tabel 17 di bawah ini.

Tabel 17. Sumber Emisi Gas Rumah Kaca di Jawa Timur

\begin{tabular}{|c|c|c|c|c|c|c|c|}
\hline \multirow{2}{*}{$\begin{array}{l}\mathbf{N} \\
\mathbf{o}\end{array}$} & \multirow{2}{*}{$\begin{array}{c}\text { Sumber } \\
\text { Emisi }\end{array}$} & \multicolumn{6}{|c|}{ Emisi Gas Rumah Kaca (Ton/tahun) } \\
\hline & & $\mathrm{CO} 2$ & CH4 & $\mathbf{N 2 0}$ & $\begin{array}{c}\text { SF } \\
6\end{array}$ & $\begin{array}{c}\text { PFC } \\
\text { S }\end{array}$ & $\begin{array}{c}\text { HCF } \\
s\end{array}$ \\
\hline \multirow[t]{6}{*}{1} & $\begin{array}{l}\text { INDUST } \\
\text { RI }\end{array}$ & & & & & & \\
\hline & $\begin{array}{l}\text { Industri } \\
\text { Semen }\end{array}$ & $\begin{array}{r}23,6 \\
3\end{array}$ & & & & & \\
\hline & $\begin{array}{l}\text { Industri } \\
\text { Kapur }\end{array}$ & $\begin{array}{r}51,1 \\
2\end{array}$ & & & & & \\
\hline & $\begin{array}{l}\text { Industri } \\
\text { Kimia }\end{array}$ & 8,32 & & 0,16 & & & \\
\hline & $\begin{array}{l}\text { Industri } \\
\text { Elektronik }\end{array}$ & & & & $\begin{array}{r}0,1 \\
1\end{array}$ & 0,09 & 0,06 \\
\hline & $\begin{array}{l}\text { Industri } \\
\text { Logam }\end{array}$ & $\begin{array}{r}15,3 \\
4 \\
\end{array}$ & & & & & \\
\hline \multirow[t]{2}{*}{2} & LIMBAH & & & & & & \\
\hline & $\begin{array}{l}\text { Limbah } \\
\text { Cair } \\
\text { Industri }\end{array}$ & & 3,42 & & & & \\
\hline \multicolumn{2}{|c|}{ Jumlah } & $\begin{array}{r}98,4 \\
1\end{array}$ & 3,42 & 0,26 & $\begin{array}{r}0,1 \\
1\end{array}$ & 0,09 & 0,06 \\
\hline
\end{tabular}




\begin{tabular}{|c|c|c|c|c|c|c|}
\hline $\begin{array}{l}\text { Jumlah (Ton } \\
\text { CO2e/tahun) }\end{array}$ & $\begin{array}{r}98,4 \\
1\end{array}$ & $\begin{array}{r}71,8 \\
2\end{array}$ & $\begin{array}{r}49,5 \\
7\end{array}$ & $\begin{array}{r}2,6 \\
4\end{array}$ & $\mathbf{9 0 , 0 0}$ & 60,00 \\
\hline $\begin{array}{l}\text { Jumlah total } \\
\text { (Ton } \\
\text { CO2e/tahun) }\end{array}$ & \multicolumn{6}{|c|}{372,44} \\
\hline
\end{tabular}

Dari tabel 17 dapat diketahui bahwa penghasil emisi Gas Rumah Kaca yang berasal dari sektor industri manufaktur beserta limbahnya menghasilkan $\mathrm{CO} 2 \mathrm{e}$ sekitar 372 juta ton per tahun. Emisi CO2 paling banyak diproduksi oleh industri kapur. Emisi $\mathrm{CH} 4$ hanya berasal dari limbah cair industri sebesar 3,42 ton setiap tahunnya.

Apabila emisi CO2e yang dihasilkan oleh masing-masing komponen di atas diurutkan dari yang terbesar hingga terkecil, maka akan menjadi seperti yang ditampilkan oleh tabel $18 \mathrm{di}$ bawah ini.

Tabel 18. Rangking Sumber Emisi Gas Rumah Kaca

\begin{tabular}{|c|l|c|c|c|}
\hline No & Sumber Emisi & $\begin{array}{l}\text { Emisi Ton } \\
\text { CO2e/thn }\end{array}$ & Rangking & $\begin{array}{l}\text { Presentase } \\
\text { (\%) }\end{array}$ \\
\hline 1 & $\begin{array}{l}\text { Industri } \\
\text { Elektronik }\end{array}$ & 152,64 & 1 & 40,97 \\
\hline 2 & $\begin{array}{l}\text { Limbah Cair } \\
\text { Industri }\end{array}$ & 71,84 & 2 & 19,28 \\
\hline 3 & Industri Kimia & 57,92 & 3 & 15,54 \\
\hline 4 & Industri Kapur & 51,12 & 4 & 13,71 \\
\hline 5 & $\begin{array}{l}\text { Industri } \\
\text { Semen }\end{array}$ & 23,63 & 5 & 6,33 \\
\hline 6 & $\begin{array}{l}\text { Industri } \\
\text { Logam }\end{array}$ & 15,34 & 6 & 4,17 \\
\hline & $\begin{array}{l}\text { Total Emisi } \\
\text { GRK } \\
\text { (Ton } \\
\text { CO2e/Tahun) }\end{array}$ & 372,49 & & 100 \\
\hline
\end{tabular}

Gambar 4 menyajikan data tentang emisi CO2e yang dihasilkan oleh induksi manufaktur di Jawa Timur.

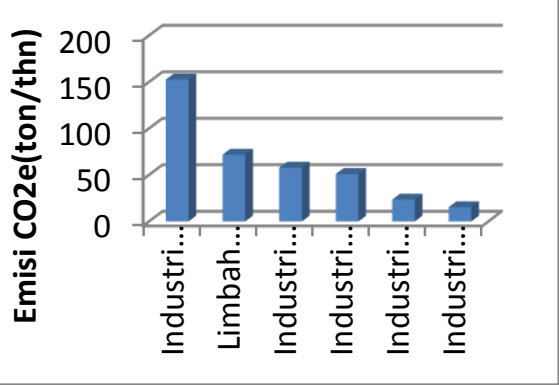

Gambar 4. Emisi CO2e

Dari tabel 18 dan Gambar 4 di atas dapat kita lihat bahwa yang menempati ranking teratas sumber emisi GRK adalah berasal dari industri elektronik dengan presentase sebesar $41 \%$, sedangkan yang berada di ranking terbawah adalah berasal dari industri logam sebesar $4 \%$.

\section{KESIMPULAN DAN SARAN}

\section{Kesimpulan}

Kondisi lapangan yang kurang bersahabat seperti letak cerobong asap, cyclone, precipitator, dan alat pengontrol emisi lainnya memberikan pengaruh yang cukup besar terhadap kevalidan data yang diperoleh. Oleh karena itu diperlukan persiapan peralatan penunjang untuk mempermudah pengambilan sampel emisi.

Dari hasil kalkulasi terhadap beberapa industri manufaktur di Jawa Timur, emisi karbon dioksida ekivalen setiap tahunnya berjumlah 372 ton. Angka ini termasuk cukup tinggi meskipun masih di bawah baku mutu emisi yang disyaratkan. Dengan demikian diperlukan upayaupaya untuk mengurangi kadar emisi sumber GRK agar efek Global Warming dapat diminilkan.

\section{Saran}

Untuk mengurangi jumlah sumber emisi GRK sebaiknya dilakukan:
a. Perbaikan proses produksi
b. Penambahan alat/bahan pereduksi emisi yang ada di saluran gas buang
c. Penyiapan alat penunjang untuk memudahkan pengambilan sampel emisi
d. Membuat peraturan yang lebih ketat mengenai standar emisi gas buang.
e. Monitoring/inspeksi gas buang oleh pihak industry dan pemerintah harus lebih disiplin.

\section{DAFTAR PUSTAKA}

Emisi Gas Rumah Kaca Dalam Angka. Asisten Deputi Urusan Data Dan Informasi Lingkungan Kementerian Negara Lingkungan Hidup, 2009

Intergovernmental Panel on Climate Change, 2006 IPCC Guidelines for National Greenhouse Gas Inventories 
Pedoman Pelaksanaan Rencana Aksi Penurunan Emisi Gas Rumah Kaca Kementerian Perencanaan Pembangunan Nasional/Badan Perencanaan Pembangunan Nasional, Tahun 2011.

Peraturan Kepala Badan Pusat Statistik Nomor 57 Tahun 2009 Tentang Klasifikasi Baku Lapangan Usaha Indonesia

Peraturan Presiden Republik Indonesia Nomor 71 Tahun 2011 Tentang Penyelenggaraan Inventarisasi Gas Rumah Kaca Nasional. Sekretaris Kabinet Deputi Bidang Kesejahteraan Rakyat, Jakarta. 